\title{
Rechtsmiddelen tegen niet-appellabele kantonuitspraken
}

\author{
Frank Bentvelzen*
}

\section{Inleiding}

Een vonnis van de kantonrechter inzake vorderingen van niet meer dan $€ 1750$ is niet vatbaar voor hoger beroep (art. 332 lid $1 \mathrm{Rv}$ ). In dergelijke gevallen staat cassatieberoep slechts op beperkte gronden open (art. 80 lid 1 Wet RO). Dit leidt ertoe dat de kantonrechter soms als enige en hoogste - nationale rechter rechtsregels uitlegt en toepast. Het is de vraag of het steeds wenselijk is dat de kantonrechter het 'laatste woord' heeft. Daarbij is niet alleen het uitblijven van controle door een hogere rechter relevant, maar ook dat uitlegvragen op deze manier bij de kantonrechter kunnen blijven steken. Dat geldt in het bijzonder voor zaken met een Unierechtelijke dimensie en/of een zaaksoverstijgend belang.

Illustratief zijn recente uitspraken van de Hoge Raad inzake geschillen naar aanleiding van geannuleerde vluchten, waarin luchtvaartmaatschappijen Aegean Airlines (hierna: Aegean) en Ryanair tegenover hun passagiers stonden. ${ }^{1}$ Aegean annuleert vluchten die door passagiers via een reisorganisatie zijn geboekt, omdat deze reisorganisatie niet in staat is de vluchtprijzen aan Aegean te voldoen. ${ }^{2}$ De annuleringen door Ryanair hebben een andere oorzaak: zij zijn het gevolg van stakingen van cabinepersoneel. ${ }^{3}$ Veel passagiers zijn gedupeerd. In procedures bij de kantonrechter bij de rechtbank Noord-Nederland (zaken tegen Aegean) en de rechtbank Oost-Brabant (zaken tegen Ryanair) vorderen zij financiële compensatie en/of restitutie van de ticketprijs. ${ }^{4}$ Zowel de kantonrechter in Noord-Nederland als de kantonrechter in Oost-Brabant wijst de vorderingen toe. Aegean en Ryanair

* Mr. F.C. Bentvelzen is werkzaam als PhD-fellow bij het Instituut voor Privaatrecht van de Universiteit Leiden.

1. HR 9 oktober 2020, ECLI:NL:HR:2020:1591, 1598 en 1599.

2. A-G Drijber, ECLI:NL:PHR:2020:367 en 368, sub 2.1-2.8; o.a. Rb. Noord-Nederland 14 november 2017, ECLI:NL:RBNNE:2017:4419, r.o. 2.1-2.5.

3. HR 9 oktober 2020, ECLI:NL:HR:2020:1591, r.o. 2.1-2.2. A-G Drijber, ECLI:NL:PHR:2020:369, sub 2.1-2.6; Rb. Oost-Brabant 23 mei 2019, ECLI:NL:RBOBR:2019:7770, r.o. 3.1-3.3.

4. Zie art. 5 lid 1 jo. art. 7 lid 1 en 8 lid 1 Verordening (EG) 261/2004 van het Europees Parlement en de Raad van 11 februari 2004 tot vaststelling van gemeenschappelijke regels inzake compensatie en bijstand aan luchtreizigers bij instapweigering en annulering of langdurige vertraging van vluchten en tot intrekking van Verordening (EEG) 295/91 (hierna: Verordening). zoeken het hogerop en gaan in cassatie. ${ }^{5}$ De directe gang van de luchtvaartmaatschappijen naar de Hoge Raad is het gevolg van art. 332 lid $1 \mathrm{Rv}$, dat hoger beroep in deze zaken onmogelijk maakt. De cassatieberoepen zijn vergelijkbaar. ${ }^{6}$ Zo wordt, naast motiveringsklachten, onder meer geklaagd dat de kantonrechter heeft geoordeeld dat de betalingsproblemen van de reisorganisatie (klacht Aegean) en de staking (klacht Ryanair) niet kunnen worden beschouwd als een 'buitengewone omstandigheid' en dat geen uitzondering op de compensatieplicht is aanvaard. ${ }^{7}$ Dit zijn rechtsklachten die volgens art. 80 lid 1 Wet RO in cassatie niet aan de orde kunnen worden gesteld. De toepassing van rechtsregels door de kantonrechters wordt dus niet beoordeeld. ${ }^{8}$

In deze bijdrage verken ik in hoeverre de mogelijkheden om rechtsmiddelen in te stellen tegen uitspraken van de kantonrechter als hoogste nationale rechter op ruimere wijze kunnen worden opgevat en ingevuld. Daartoe bespreek ik eerst het juridisch kader dat appel- en cassatiemogelijkheden beperkt (par. 2). Vervolgens bespreek ik aan de hand van daaruit voortvloeiende kwesties de wenselijkheid van ruimere mogelijkheden (par. 3) en geef ik aan waar voor die mogelijkheden wellicht ruimte ligt en hoe die mogelijkheden vorm zouden kunnen krijgen (par. 4). Ik bespreek de beperkingen en mogelijkheden naar Nederlands recht in brede zin, maar besteed daarbinnen eveneens bijzondere aandacht aan de gevallen waarin de kantonrechter Unierecht moet toepassen. In die gevallen kunnen aanvullende argumenten voor ruimere mogelijkheden een rol spelen. Dit speelde in de hierboven benoemde luchtvaartzaken, waarin Unierecht van toepassing was en waarin de luchtvaartmaatschappijen de beperkingen probeerden te omzeilen, met een beroep op de bijzondere

5. Aegean stelt tweemaal tegen drie nagenoeg identieke uitspraken tegelijk cassatie in. Rb. Noord-Nederland had de betreffende procedures verdeeld over twee gezamenlijke behandelingen van elk drie zaken. De eindvonnissen in de procedures jegens Aegean, op 19 februari 2019 gewezen en materieel gelijkluidend (A-G Drijber, ECLI:NL:PHR:2020:367 en 368, sub 1.3 en 3.3-3.5), zijn bij mijn weten (nog) niet gepubliceerd. Ryanair gaat in cassatie tegen Rb. Oost-Brabant 23 mei 2019, ECLI:NL:RBOBR: 2019:7770.

6. Zie de betreffende conclusies van A-G Drijber, ECLI:NL:PHR: 2020:367, 368 en 369 (hierna, tenzij anders vermeld: A-G Drijber).

7. Middel Aegean, subonderdeel 1.3; middel Ryanair, subonderdeel 1.1; zie art. 5 lid 3 Verordening.

8. HR 9 oktober 2020, ECLI:NL:HR:2020:1591, r.o. 3.1.3-3.1.4 
status van het Unierecht. ${ }^{9}$ Ik sluit af met een conclusie (par. 5).

\section{Beperking van hoger beroep en cassatie}

\subsection{Wettelijke uitsluiting van hoger beroep; \\ doorbrekingsjurisprudentie niet van toepassing}

Art. 332 lid $1 \mathrm{Rv}$ bepaalt dat tegen een vonnis geen hoger beroep mogelijk is wanneer de waarde van de vordering in eerste aanleg niet meer beloopt dan $€ 1750$. In die zaken beslist de kantonrechter (art. 93 sub a Rv). De ratio van de appelgrens is dat hoger beroep niet moet openstaan in zaken waarvan het geringe financiële belang niet opweegt tegen de tijd en kosten die gemoeid zijn met de behandeling van de zaak in hoger beroep. ${ }^{10}$ Deze ratio wordt ruim uitgelegd. De appelgrens voorkomt enerzijds dat het rechterlijk apparaat belast wordt met zaken betreffende relatief kleine vorderingen, en beschermt anderzijds tegen hoge proceskosten. ${ }^{11}$ Kostbare en tijdrovende appelprocedures zouden rechtzoekenden kunnen ontmoedigen kleinere vorderingen in te stellen. ${ }^{12}$ Ook als wordt geoordeeld met toepassing van de Europese 'Small Claims-procedure' geldt deze grens, zie art. 2 lid 2 Uitvoeringswet verordening Europese procedure voor geringe vorderingen. ${ }^{13}$

Ten behoeve van de appellabiliteit mag de waarde van de afzonderlijke vorderingen niet worden opgeteld. $\mathrm{Nu}$ geen enkele individuele vordering van de passagiers de appelgrens te boven ging, waren de kantonuitspraken in de zaken van Aegean en Ryanair dus niet-appellabel. Optellen kan alleen bij

9. De passagiers hadden hun claims immers gebaseerd op de Verordening. Ook klagen ze dat de kantonrechter ten onrechte geen prejudiciële vragen aan het Hof van Justitie van de EU heeft gesteld (art. 267 lid 3 VWEU), zie middel Aegean en Ryanair, subonderdeel 1.4.

10. HR 16 maart 2007, ECLI:NL:HR:2007:AZ1490, NJ 2007/637 (Johannes/Baranco), r.o. 3.6. Zie met betrekking tot art. 2 lid 2 Uitvoeringswet verordening Europese procedure voor geringe vorderingen (hierna: UwEPGV), Kamerstukken II 2007/08, 31596, nr. 3, p. 10.

11. A-G Wesseling-van Gent in haar conclusie voor Johannes/Baranco, sub 2.5; Van Geuns \& Jansen, in: GS Burgerlijke Rechtsvordering, art. 332, aant. 3. F.J.H. Hovens, Het civiele hoger beroep (diss. Tilburg), Deventer: Kluwer 2005, p. 55, benadrukt het algemeen belang.

12. H.J. Snijders, C.J.M. Klaassen \& G.J. Meijer, Nederlands burgerlijk procesrecht, Deventer: Wolters Kluwer 2017/255; H.J. Snijders \& A. Wendels, Civiel appel, Deventer: Kluwer 2009/36.

13. Op grond van Verordening (EG) $861 / 2007$ tot vaststelling van een Europese procedure voor geringe vorderingen, gewijzigd door Verordening (EU) 2015/2421, kan van deze goedkope, snelle en eenvoudige procedure bij vorderingen van maximaal $€ 5000$ in grensoverschrijdende geschillen gebruik worden gemaakt. Een aantal onderdelen van deze verordening is uitgewerkt in de UwEPGV. Hierover C.M.D.S. Pavillon \& L. Bos, 'Small massaclaims. De inzet van de Europese Procedure voor Geringe Vorderingen (EPGV) bij de afwikkeling van grensoverschrijdende massaschade', $T v C$ 2020, afl. 3, p. 119-128. Hetgeen hierna met betrekking tot art. $332 \mathrm{Rv}$ wordt opgemerkt, geldt ook voor art. 2 lid 2 UwEPGV, tenzij anders vermeld. In enkele zaken tegen Aegean werd deze procedure toegepast, zie A-G Drijber, ECLI:NL:PHR:2020:367 en 368, sub 3.3-3.5. vorderingen tussen dezelfde partijen (art. 332 lid $2 \mathrm{Rv}$ ). ${ }^{14}$ In dit geval hadden verschillende partijen de luchtvaartmaatschappijen in rechte aangesproken. ${ }^{15}$

De appelgrens van art. $332 \mathrm{Rv}$ is een voorbeeld van een wettelijke bepaling waarin een of meer rechtsmiddelen worden uitgesloten. Andere voorbeelden zijn art. 1019bb Rv (deelgeschilprocedure) of art. 3:268 lid $3 \mathrm{BW}$ (toestemming voor onderhandse verkoop van verhypothekeerde goederen). Deze voorbeelden zien, anders dan art. $332 \mathrm{Rv}$, op specifieke beslissingen. Bovendien laten zij zien dat een appelverbod gepaard kan gaan met uitsluiting van beroep in cassatie. Bepalingen die slechts hoger beroep uitsluiten, zal ik hierna aanduiden als 'appelverbod', bij uitsluiting van hoger beroep én cassatie spreek ik van een 'rechtsmiddelenverbod'.

Een eiser in hoger beroep of cassatie wordt ondanks een rechtsmiddelenverbod toch ontvankelijk geacht, als hij klaagt dat de rechter in vorige aanleg het artikel waarop de betreffende beslissing is gegrond ten onrechte heeft toegepast of niet toegepast, of heeft toegepast met verzuim van essentiële vormen. ${ }^{16}$ Het laatste geval betreft een schending van zo fundamentele rechtsbeginselen dat geen sprake meer is van een eerlijke en onpartijdige behandeling van de zaak. Daarvoor is schending van de motiveringsplicht niet toereikend. ${ }^{17}$ In zulke gevallen wordt het rechtsmiddelenverbod 'doorbroken'.

Volgens vaste rechtspraak kan het appelverbod voor kleine vorderingen (art. 332 lid $1 \mathrm{Rv}$ ) juist niet worden doorbroken. ${ }^{18}$ Ook hier speelt een rol dat de geringe waarde van de

14. Parl. Gesch. Rv 2002, p. 458; Asser Procesrecht/Bakels, Hammerstein \& Wesseling-van Gent 4 2018/20; Asser Procesrecht/Korthals Altes \& Groen 7 2015/46. Zie o.a. HR 3 april 1981, ECLI:NL:HR: 1981:AG4175, NJ 1982/184 (Gefau/Vermeij e.a.) - ook over vliegreisperikelen; HR 25 maart 1994, ECLI:NL:HR:1994:ZC1315, NJ 1994/392 (Ten Haave \& Botman/HRB), r.o. 3; Hof Amsterdam 11 februari 2020, ECLI:NL:GHAMS:2020:476, r.o. 2.7; Hof Amsterdam 8 oktober 2019, ECLI:NL:GHAMS:2019:3623, r.o. 3.3-3.4.

15. In een andere zaak is door Qatar Airways betoogd dat voor de toepassing van de appelgrens individuele vorderingen wel bij elkaar moeten worden opgeteld als een gezamenlijk lasthebber die vorderingen als één vordering heeft ingesteld. Hof Amsterdam 8 oktober 2019, ECLI:NL:GHAMS: 2019:3623 ging hierin niet mee. Qatar Airways is met onder meer Unierechtelijke klachten tegen dat oordeel opgekomen en benadrukt dat sprake is van een 'zaaksoverstijgende kwestie van fundamentele aard'. HR 9 april 2021, ECLI:NL:HR:2021:530 heeft het cassatieberoep inmiddels verworpen met toepassing van art. 81 lid 1 Wet RO. A-G Drijber, ECLI:NL:PHR:2020:1085 concludeerde al eerder tot verwerping. Ik laat deze zaak hierna, los van een enkele verwijzing naar de conclusie, buiten beschouwing.

16. HR 29 maart 1985, ECLI:NL:HR:1985:AG4989, NJ 1986/242 (Enka) Dupont), r.o. 3.2; HR 5 juli 2019, ECLI:NL:HR:2019:1085, NJ $2019 / 423$, r.o. 3.4 .

17. HR 4 maart 1988, ECLI:NL:HR:1988:AB8701, NJ 1989/4 (HBM/ Wielenga), r.o. 3.3; HR 18 april 2014, ECLI:NL:HR:2014:943, NJ 2015/215 (Schijf c.s./Laclé), r.o. 5.2. Over deze maatstaf F.C. Bentvelzen, 'Doorbreking van rechtsmiddelenverboden en schending van de motiveringsplicht', $A A$ 2019a, afl. 10, p. 796-802 en F.C. Bentvelzen, 'Cassatieberoep en uitsluiting daarvan in het licht van art. 6 EVRM', WPNR 2019b, afl. 7256, p. 730-737.

18. Dit gold al voor art. $38 \mathrm{Wet} \mathrm{RO}$ (oud) - voorganger van art. $332 \mathrm{Rv}$ - en art. 66 Algemene Bijstandswet (oud), zie HR 19 december 1986, ECLI:NL:HR:1986:AC9636, NJ 1987/1000 (Citroen/Vos) en HR 12 april 1991, ECLI:NL:HR:1991:ZC0210, NJ 1992/215 (Ben Amor) Groningen), r.o. 3.3. 
vordering niet opweegt tegen de kosten en tijd die met hoger beroep zijn gemoeid. ${ }^{19}$ De Hoge Raad voegt hieraan toe dat er geen aanleiding is voor doorbreking van art. 332 lid $1 \mathrm{Rv}$, omdat tegen vorderingen van geringe omvang wel cassatieberoep openstaat op de voet van art. $80 \mathrm{Wet} R O{ }^{20}$ Dat cassatieberoep is beperkt, zo blijkt uit de volgende paragraaf.

\subsection{Cassatieberoep op beperkte gronden}

\section{Beperkte ruimte voor rechtsklachten}

Volgens art. 80 lid 1 Wet RO kan tegen kantonuitspraken waartegen geen hoger beroep openstaat, op vier gronden cassatieberoep worden ingesteld. Naast onbevoegdheid (sub c) en overschrijding van rechtsmacht (sub d), is cassatie slechts mogelijk wanneer de uitspraak niet in het openbaar is gedaan (sub b) of wanneer de uitspraak niet de gronden bevat waarop de uitspraak berust (sub a). ${ }^{21}$ Cassatieklachten wegens schending van recht, anders dan in art. 80 lid 1 Wet RO genoemd, ${ }^{22}$ zijn in beginsel niet mogelijk. Ook motiveringsklachten die nopen tot een rechtsoordeel - verkapte rechtsklachten - zijn niet-ontvankelijk. ${ }^{23}$ Art. 80 lid 1 Wet RO is wat cassatieklachten betreft dus beperkter dan art. 79 Wet RO in een reguliere cassatieprocedure. Evenals de appelgrens van art. $332 \mathrm{Rv}$ beoogt deze beperking zowel bescherming van de rechtzoekende tegen kostbare procedures als het voorkomen van overbelasting van het rechterlijk apparaat. ${ }^{24}$

De Hoge Raad heeft in het arrest Johannes/Baranco de gronden in art. 80 lid 1 Wet RO aangevuld. ${ }^{25}$ In de procedure voorafgaand aan het arrest had de kantonrechter de comparitie laten doorgaan, terwijl een van de partijen had aangegeven niet te kunnen verschijnen wegens verblijf in het buitenland. De Hoge Raad oordeelt dat de daaropvolgende klacht over vermeende schending van hoor en wederhoor, ondanks de limitatieve opsomming in art. 80 lid $1 \mathrm{Wet}$ RO, in cassatie kan worden beoordeeld. De Hoge Raad overweegt dat in het licht van de ontwikkelingen inzake de fundamentele beginselen van procesrecht onder invloed van art. 6 EVRM en de daarop gevormde rechtspraak van het Europees Hof voor de Rechten van de Mens (EHRM) en de Hoge Raad niet meer kan worden volstaan met de beperking tot de in art. 80 lid 1 Wet RO genoemde beginselen van procesrecht (motiveringsplicht en openbaarheid van de uitspraak), en dat

19. Johannes/Baranco, r.o. 3.6. De wetgever neemt hetzelfde aan voor art. 2 lid 2 UwEPGV, zie Kamerstukken II 2007/08, 31596, nr. 3, p. 10.

20. Johannes/Baranco, r.o. 3.6; Ben Amor/Groningen, r.o. 3.3; Hof Leeuwarden 28 april 2009, ECLI:NL:GHLEE:2009:BI5014, r.o. 2.

21. Sub a betreft schending van motiveringseisen in brede zin, en niet slechts ontbreken van motivering. A.E.H. van der Voort Maarschalk, 'De toetsing in cassatie', in: B.T.M. van der Wiel (red.), Cassatie, Deventer: Wolters Kluwer 2019/88; W.D.H. Asser, Civiele cassatie, Nijmegen: Ars Aequi Libri 2018, p. 32; Asser Procesrecht/Korthals Altes \& Groen 7 2015/197.

22. Vgl. Asser 2018, p. 31.

23. Van der Voort Maarschalk 2019/89.

24. A-G Drijber, ECLI:NL:PHR:2020:367, sub 4.13; Asser Procesrecht/ Korthals Altes \& Groen 7 2015/196; Snijders, Klaassen \& Meijer $2017 / 272$.

25. HR 16 maart 2007, ECLI:NL:HR:2007:AZ1490, NJ 2007/637 (Johannes/Baranco). 'tevens als grond voor cassatie [moet] worden aanvaard dat een zo fundamenteel rechtsbeginsel is geschonden dat van een eerlijke en onpartijdige behandeling van de zaak niet kan worden gesproken, zoals het geval is bij het niet inachtnemen van het contradictoire beginsel, waartoe behoort hoor en wederhoor, en van het recht op gelijke behandeling (equality of arms)'. ${ }^{26}$

De Hoge Raad vult zo art. 80 lid 1 Wet RO aan met een aan de doorbrekingsjurisprudentie ontleende grond, om vervolgens vast te houden aan zijn lijn dat het appelverbod van art. $332 \mathrm{Rv}$ niet kan worden doorbroken, ook als de rechter in eerste aanleg fundamentele rechtsbeginselen heeft geschonden. ${ }^{27}$

Geen procesrechtelijke status aparte voor het Unierecht Moet op de beperkte cassatiegronden van art. 80 lid 1 Wet $\mathrm{RO}$ en de hierboven besproken aanvulling geen uitzondering worden gemaakt waar het gaat om klachten over schending van Unierecht? Tot voor kort liet de Hoge Raad zich hierover niet expliciet uit, ${ }^{28}$ maar het cassatieberoep van Aegean en Ryanair gaf de Hoge Raad een nieuwe kans. De vorderingen in eerste aanleg tot compensatie en restitutie van de ticketprijzen waren namelijk gebaseerd op Verordening (EG) 261/2004. Het cassatiemiddel bepleit uitbreiding van de gronden in art. 80 lid 1 Wet $\mathrm{RO}$, althans buiten toepassing verklaren daarvan, waar het betreft klachten over schending van Unierecht door de kantonrechter of het nalaten van het stellen van prejudiciële vragen aan het Hof van Justitie van de EU (hierna: Hof van Justitie). ${ }^{29}$

De Hoge Raad benut deze nieuwe kans in de zaak van Ryanair in zijn arrest van 9 oktober 2020. Na bespreking van de cassatiegronden in art. 80 lid 1 Wet RO en de uitbreiding in Johannes/Baranco overweegt de Hoge Raad:

'Er bestaat geen aanleiding de in art. 80 lid $1 \mathrm{RO}$ genoemde gronden van cassatie uit te breiden zoals door het middel voorgestaan. Het Unierecht vormt immers onderdeel van de Nederlandse rechtsorde en neemt voor

26. Johannes/Baranco, r.o. 3.7.2. Zie ook HR 21 september 2012, ECLI:NL:HR:2012:BW4896, NJ 2013/351 (Betsalel/Stichting Joodse Omroep), r.o. 4.2.2; Hof 's-Hertogenbosch 12 juli 2016, ECLI:NL:GHSHE:2016:2836, r.o. 3.9; in het kader van de UwEPGV: Hof Arnhem-Leeuwarden 11 april 2019, ECLI:NL:GHARL:2019:3239, 3245, 3247 en 3425; vgl. Hof 's-Hertogenbosch 13 augustus 2019, ECL:NL:GHSHE:2019:3023, r.o. 2.5 .

27. Johannes/Baranco, r.o. 3.8.

28. Uit HR 3 mei 2013, ECLI:NL:HR:2013:BZ2868, NJ 2013/277 (Transavia/Racadio e.a.), r.o. 2.4 .2 bleek al wel het prevaleren van de beperkte cassatie voor niet-appellabele kantonuitspraken boven controle op toepassing van Unierecht; Asser 2018, p. 33.

29. Het middel onderscheidt hier schending van Unierecht van schending van de plicht prejudiciële vragen te stellen. Met A-G Drijber, sub 4.2, zie ik de laatste klacht als een bijzondere vorm van de eerste. 
de toepassing van art. 80 lid $1 \mathrm{RO}$ geen uitzonderingspositie in.' 30

Het gegeven dat een klacht ziet op schending van Unierecht vormt voor de Hoge Raad dus geen grond voor uitbreiding van de cassatiemogelijkheden tegen een niet-appellabele kantonuitspraak. Hierin volgt de Hoge Raad A-G Drijber, die in zijn conclusie opmerkt dat het Unierecht net zo moet worden behandeld als andere rechtsbronnen. De A-G acht het principieel onjuist het Unierecht in procesrechtelijke zin een status aparte te geven. Ook het doeltreffendheidsbeginsel noopt daar zijns inziens niet toe. ${ }^{31}$

\section{Wenselijkheid van ruimere mogelijkheden in hoger beroep en cassatie}

\subsection{Kanttekeningen in het licht van rechtsbescherming, rechtseenheid en rechtsontwikkeling}

De combinatie van de harde appelgrens van art. 332 lid $1 \mathrm{Rv}$ met de door art. 80 lid 1 Wet RO beperkte mogelijkheden van cassatieberoep tegen kantonuitspraken laat bijna geen ruimte voor een inhoudelijke beoordeling van de beslissing van de kantonrechter in zaken over kleine vorderingen.

Ter verdediging van deze beperkingen kan worden aangevoerd dat uit art. $6 \mathrm{EVRM}$, dat het recht op een eerlijk proces waarborgt, geen recht op toetsing door een hogere rechter kan worden afgeleid. ${ }^{32}$ Bovendien bevordert de combinatie van het uitsluiten van hoger beroep en het beperkte cassatieberoep in zekere zin de toegang tot de rechter, door de procedure en daarmee gemoeide kosten op voorhand te beperken. ${ }^{33}$ Als het aankomt op belangen van rechtseenheid en rechtsontwikkeling is er een inmiddels beproefd alternatief: de mogelijkheid

30. HR 9 oktober 2020, ECLI:NL:HR:2020:1591, r.o. 3.1.4. De Hoge Raad geeft gehoor aan de opmerking van A-G Drijber, ECLI:NL:PHR: 2020:369, sub 4.39, die een oordeel op dit punt in het belang van de rechtsvorming acht, en doet de zaak niet af met toepassing van art. 81 lid 1 Wet RO. De zaken van Aegean worden in HR 9 oktober 2020, ECLI:NL:HR:2020:1598 en 1599 wel met toepassing van art. 81 lid 1 Wet RO afgedaan.

31. A-G Drijber, sub 3.31 .

32. P. Smits, Artikel 6 EVRM en de civiele procedure, Deventer: Kluwer 2008, p. 56-57; EHRM 17 januari 1970, serie A, vol. 11 (Delcourt), par. 25; A-G Drijber, ECLI:NL:PHR:2020:1085, sub 3.36. Wanneer beroep openstaat, moet die beroepsprocedure wel voldoen aan de waarborgen van art. 6 EVRM. Zie ook Snijders, Klaassen \& Meijer 2017/52, EHRM 26 oktober 1984, ECLI:CE:ECHR:1984:1026JUD000918, NJ 1988/744 (De Cubber/België) en EHRM 16 februari 2017, ECLI:CE:ECHR:2017:0216JUD001898606. Ook het Unierecht (zie art. $47 \mathrm{EU}$-Grondrechtenhandvest) vereist geen rechtspraak in twee instanties, zolang er een rechterlijke instantie is die bevoegd is om op grond van art. 267 VWEU prejudiciële vragen te stellen. Zie A-G Drijber, ECLI:NL:PHR:2020:1085, sub 3.33 en 36, met verwijzing naar o.a. HvJ EU 6 maart 2018, ECLI:EU:C:2018:158 (Slowakije/Achmea), r.o. 56-58.

33. Zie ook par. 2.1 en vgl. A-G Drijber, ECLI:NL:PHR:2020:1085, sub 2.6, $3.17,3.19$ en 3.36 voor feitenrechters om prejudiciële vragen te stellen aan de Hoge Raad. ${ }^{34}$

Toch kunnen bij dit systeem enkele belangrijke kanttekeningen worden geplaatst. Om met de laatstgenoemde mogelijkheid te beginnen: een tussentijdse stap naar de Hoge Raad voor antwoorden op rechtsvragen is niet zonder tijd en kosten, en vereist wellicht nader feitenonderzoek. ${ }^{35}$ Bovendien is de mogelijkheid van het stellen van prejudiciële vragen afhankelijk van de bereidheid van de feitenrechter om vragen te stellen. Zo heeft geen van de bij de luchtvaartzaken betrokken kantonrechters deze stap genomen. Ten slotte zou het argument ook kunnen worden omgedraaid: als prejudiciële vragen mogelijk zijn bij rechtsvragen die veel en talrijk spelen, waarom zou in die zaken dan geen hoger beroep of cassatie mogelijk zijn?

Een andere kanttekening is meer technisch van aard. De keuze voor motiverings- boven rechtsklachten is weinig overtuigend, althans vanuit het perspectief van de ratio van art. $332 \mathrm{Rv}$ en art. 80 lid $1 \mathrm{Wet} \mathrm{RO}$. Ten eerste kan het totale financiële belang dat is gemoeid met een rechtsvraag die speelt in vele vergelijkbare zaken aanzienlijk hoger liggen dan de appelgrens. Denk opnieuw aan de vorderingen in de luchtvaartzaken. ${ }^{36}$ Deze kritiek, die vooral klinkt in het kader van de roep om uitbreiding of afschaffing van het reeds lang bekritiseerde art. 80 lid 1 Wet RO, ${ }^{37}$ leidde nog niet tot aanpassing van de wet of de lijn in de rechtspraak. Ten tweede laten de tijd en kosten gemoeid met rechtsklachten en motiveringsklachten zich lastig in het algemeen vergelijken vanuit het perspectief van tijd en kosten. Een rechtsklacht kan het resultaat zijn van een enkele blik in het dossier, maar ook van een intensieve studie van het toepasselijke juridisch kader. Hetzelfde geldt voor motiveringsklachten. Uit een dun kantondossier kunnen motiveringsgebreken makkelijk zijn te destilleren, maar niet alle kantondossiers zijn dun en bovendien vergen sommige motiveringsklachten een gedetailleerde reconstructie en duiding van de procedure in verband met de aan cassatiemiddelen gestelde eisen (art. 407 lid $2 \mathrm{Rv}$ ). ${ }^{38}$ Het is dus niet zo evident om motiveringsklachten omwille van de efficiëntie de voorkeur te geven. Een rechtvaardiging voor die voorkeur kan mijns inziens ook niet worden gevonden in het essentiële karakter van de motiveringsplicht, juist nu de Hoge Raad

34. Deze mogelijkheid wordt voor art. 80 Wet RO-zaken aangenomen; Van der Voort Maarschalk 2019/92; Hof Amsterdam 8 oktober 2019, ECLI:NL:GHAMS:2019:3623, r.o. 3.9. Voorts kan worden gewezen op cassatie in het belang der wet, al wordt in de literatuur opgemerkt dat dit instrument terughoudend wordt toegepast, zie Asser Procesrecht/Korthals Altes \& Groen 72015/62, Asser 2018, p. 138, Van der Voort Maarschalk 2019/459 en A.M. Mennens, Het dwangakkoord buiten surseance en faillissement, Deventer: Wolters Kluwer 2020/594.

35. H.B. Krans \& A.G. Castermans, 'Het bewijsrecht in de schijnwerper, voortdurend', in: R.H. de Bock, R.J.Q. Klomp \& E.L. Schaafsma-Beversluis (red.), Voor Daan Asser (Asser-bundel), Deventer: Wolters Kluwer 2020, p. 171-173.

36. Van der Voort Maarschalk 2019/97. Zie ook de recente Airbnb-zaken, o.a. Rb. Amsterdam 9 maart 2020, ECLI:NL:RBAMS:2020:1477, waarover Pavillon \& Bos 2020, p. 123-124.

37. Haardt, NJ 1988/338; Asser Procesrecht/Korthals Altes \& Groen 7 2015/196; Snijders, Klaassen \& Meijer 2017/272.

38. Vgl. Asser 2018, p. 89-91. 
motiveringsgebreken niet beschouwt als een fundamentele schending die doorbreking rechtvaardigt (par. 2.1).

Vanuit het oogpunt van rechtsbescherming, rechtseenheid en rechtsontwikkeling is er veel voor te zeggen de combinatie van uitsluiting van hoger beroep en beperking van cassatieberoep op de schop te nemen. Het is maar moeilijk te verkroppen dat evident onjuiste kantonvonnissen niet kunnen worden getoetst in cassatie, zolang de motivering maar voldoet aan de gestelde eisen. ${ }^{39}$ De rechtseenheid en rechtsontwikkeling zijn ermee gediend om uitspraken met een zaaksoverstijgend belang voor te kunnen leggen aan een hogere rechter.

\subsection{Unierechtelijke druk op de schouders van de kantonrechter?}

Een aanvullende reden voor het uitbreiden van de mogelijkheden om kantonuitspraken aan een hogere rechter voor te leggen kan worden gevonden in het feit dat de kantonrechter in vele zaken als laatste en hoogste nationale instantie Unierecht toepast. Denk aan consumentengeschillen, waarin vaak regels van Europese origine aan de orde zijn en het financieel belang gering is. ${ }^{40}$ In dat soort zaken - met als concreet voorbeeld weer de luchtvaartzaken - is bijna vanzelfsprekend sprake van een zaaksoverstijgend belang.

In deze context liggen vergissingen van de kantonrechter bij de uitleg en toepassing van Unierecht - inclusief het niet stellen van prejudiciële vragen aan het Hof van Justitie wanneer de uitleg van Unierecht niet buiten redelijke twijfel staat (art. 267 VWEU) ${ }^{41}$ - op de loer. ${ }^{42}$ Die vergissingen treffen niet alleen de betrokken partijen, maar mogelijkerwijs ook de Staat. Sinds het Köbler-arrest kunnen lidstaten aansprakelijk worden gehouden wanneer de in laatste aanleg rechtsprekende instantie een toepasselijke Unierechtelijke regel, die ertoe strekt particulieren rechten toe te kennen, heeft geschonden, met schade als gevolg. De schending moet voldoende gekwalificeerd zijn. Gelet op de specifieke aard van de rechterlijke functie en de gerechtvaardigde eisen van rechtszekerheid is daarvan pas sprake als de rechter het toepasselijke

39. Heemskerk, NJ 1979/524; Snijders, Klaassen \& Meijer 2017/272.

40. Vgl. H.B. Krans, 'De kantonrechter als hoogste rechter', WPNR 2004 , afl. 6595, p. 829. Daarbij komt dat deze regels vaak ambtshalve moeten worden toegepast. Het nalaten van deze ambtshalve toetsing is extra problematisch wanneer daartegen geen rechtsmiddel openstaat, waarover J.M.L. van Duin, Justice for both. Effective judicial protection under Article 47 of the EU Charter of Fundamental Rights and the Unfair Contract Terms Directive (diss. Amsterdam UvA), 2020, p. 237.

41. Die verplichting rust op de rechter die in het concrete geval de hoogste rechter is. HvJ EG 4 juni 2002, ECLI:EU:C:2002:329, NJ 2003/120 (Lyckeskog), waarover Krans 2004, p. 828 en H.B. Krans, Nederlands burgerlijk procesrecht en materieel EU-recht, Deventer: Kluwer 2010, p. 126. Zie ook HvJ EU 15 maart 2017, ECLI:EU:C:2017:209, AB 2017/140 (Aquino). Geen verwijzingsplicht bestaat als de betreffende bepaling al door het Hof is uitgelegd (acte éclairé), of de juiste toepassing zo evident is dat redelijkerwijs geen twijfel kan bestaan over de uitleg (acte clair); HvJ EG 6 oktober 1982, ECLI:EU:C:1982:335 (Cilfit), r.o. 14-17; HvJ EU 4 oktober 2018, ECLI:EU:C:2018:811 (Commissie/Frankrijk).

42. Bij kantonrechters is de kans op Unierechtelijke vergissingen waarschijnlijk groter dan bij hogere rechtscolleges. Kantonrechters hebben in absolute zin meer zaken te behandelen en zijn - ook wanneer zij in laatste instantie rechtspreken - alleensprekende rechters, zonder conclusie van de procureur-generaal; Krans 2004, p. 832; Krans 2010, p. 127. recht 'kennelijk' heeft geschonden. ${ }^{43}$ Köbler-aansprakelijkheid is gereserveerd voor uitzonderlijke gevallen. ${ }^{44} \mathrm{Bij}$ de beoordeling of sprake is van een 'kennelijke schending' gelden als gezichtspunten onder meer de mate van duidelijkheid en nauwkeurigheid van de geschonden regel, of de schending opzettelijk is begaan, of de rechtsdwaling verschoonbaar is, het eventueel door een gemeenschapsinstelling ingenomen standpunt en de schending van de plicht een prejudiciële vraag te stellen. ${ }^{45}$

Dat een verkeerde toepassing van het Unierecht door de kantonrechter niet snel tot staatsaansprakelijkheid leidt, neemt de onwenselijkheid van die verkeerde toepassing niet weg. Daar komt bij dat als de staatsaansprakelijkheid een lidstaat wél treft, dit nog niet eens de juiste toepassing van Unierecht in het concrete geval meebrengt. ${ }^{46}$ Invloed van nieuwe Europese regelgeving op nationaal privaatrecht vraagt juist voortdurend om toepassing en interpretatie van die regelgeving. Ook hierom is eenvormige duiding door een hoger college noodzakelijk. ${ }^{47}$

Als oplossing is voor kantonzaken met Unierechtelijke aspecten die thans niet-appellabel zijn, voorgesteld om appel toe te laten, of art. 80 lid 1 Wet RO te verruimen. De 'Unierechtelijke druk' op de kantonrechter kan daarmee wat worden verlicht. ${ }^{48}$ Met het oog op een meer eenvormige uitleg van Unierecht door een hoger nationaal college zijn deze suggesties het overwegen waard, als aanvulling op het thans geldende stelsel van rechtsmiddelen.

In dit verband kan worden tegengeworpen dat kantonrechters, wanneer zij hoogste rechter zijn, bij uitlegkwesties de plicht hebben prejudiciële vragen te stellen aan het Hof van

43. HvJ EG 30 september 2003, ECLI:EU:C:2003:513, NJ 2004/160 (Köbler), r.o. 53. Zie o.a. T. Barkhuysen \& M.L. van Emmerik, 'Staatsaansprakelijkheid voor rechterlijk optreden vanwege schending van het EVRM', O\& $A$ 2017/34, p. 102-103.

44. HvJ EG 30 september 2003, ECLI:EU:C:2003:513, NJ 2004/160 (Köbler), r.o. 53; Krans 2004, p. 828; Krans 2010, p. 123; M.H. Wissink \& R. Meijer, 'Köbler: staatsaansprakelijkheid voor schending van gemeenschapsrecht door hoogste rechterlijke instanties', VrA 2004, afl. 1, p. 99-100.

45. Köbler, r.o. 53-55; HvJ EG 13 juni 2006, ECLI:EU:C:2006:391, NJ 2006/543 (Traghetti); HvJ EU 29 juli 2019, ECLI:EU:C:2019:630 (Hochtief). Het ten onrechte achterwege laten van prejudiciële vragen door een kantonrechter wiens uitspraken niet vatbaar zijn voor hogere voorziening, is dus slechts een gezichtspunt en op zichzelf onvoldoende voor een kennelijke schending, zie HR 21 december 2018, ECLI:NL:HR:2018:2396, NJ 2019/156 (KLM-piloten/Staat), r.o. 3.3.6 en R. Ortlep \& R.J.G.M. Widdershoven, 'Staat niet aansprakelijk voor niet prejudicieel verwijzen', O\& $A$ 2019/20, p. 48-49. Vgl. Wissink \& Meijer 2004, p. 100-101.

46. In dat opzicht is de staatsaansprakelijkheid geen effectieve remedie; Van Duin 2020, p. 54; vgl. J. Uzman, Constitutionele remedies bij schending van grondrechten: over effectieve rechtsbescherming, rechterlijk abstineren en de dialoog tussen rechter en wetgever (diss. Leiden), Deventer: Kluwer 2013, p. 333 en 361.

47. Zie in dit verband Rb. Amsterdam 17 maart 2020, ECLI:NL:RBAMS: 2020:2275, r.o. 18: 'In Nederland ontbreekt in luchtvaartzaken rechtspraak in hoger beroep als gevolg van het niet voldoen aan de appellabiliteitsgrens van $€ 1.750$,- van de individuele claims van de passagiers (zie onder meer ECLI:NL:GHAMS:2019:3623) hetgeen omwille van de rechtseenheid en rechtsvormende werking die hiervan zou uitgaan, nuttig was geweest (...).'

48. Krans 2004, p. 832-833; Krans 2010, p. 127. 
Justitie (zie hierboven). Voorts wordt erop gewezen dat kantonrechters prejudiciële vragen aan de Hoge Raad kunnen stellen. De Hoge Raad kan zich dan op zijn beurt weer wenden tot het Hof van Justitie. ${ }^{49}$ Daarnaast is aangevoerd dat kantonrechters zelf, ook zonder rol van hoogste rechter, de prejudiciële gang naar het Hof van Justitie niet lijken te schuwen als zij Unierechtelijk getinte beslissingen moeten nemen. Hierbij wordt gewezen op eerdere zaken waarin Verordening (EG) 261/2004 een rol speelde. ${ }^{50}$

Dat kantonrechters de stap naar het Hof van Justitie niet schuwen, garandeert echter niet dat zij deze gang - waar geraden - altijd zullen maken, ook niet wanneer het gaat om kantonrechters die hoogste rechters zijn. Uit recent onderzoek onder Nederlandse, niet-verwijzingsplichtige, feitenrechters blijkt dat zij hun beslissing om wel of geen prejudiciële vraag aan het Hof te stellen met name baseren op pragmatische en praktische overwegingen, alsmede op persoonlijke en institutionele factoren. ${ }^{51}$ Zo kunnen zittingsdruk en onbekendheid met de prejudiciële procedure bij het Hof meespelen bij het al dan niet verwijzen. ${ }^{52}$ Het is denkbaar dat dergelijke overwegingen ook kunnen meespelen bij de beslissing om niet te verwijzen wanneer de kantonrechter wel de hoogste, en dus verwijzingsplichtige, rechter is. ${ }^{53}$ Het is bovendien niet uitgesloten dat een kantonrechter een mogelijke Unierechtelijke uitlegkwestie niet onderkent en daarmee zelf onbewust als laatste rechter invulling geeft aan een rechtsregel..$^{54} \mathrm{Bij}$ onjuiste toepassing van de regel staan partijen op nationaal niveau

49. A-G Drijber, sub 4.33. J. Langer \& J. Krommendijk, 'De verwijzingsplicht van de hoogste rechters in Nederland en de Cilfit-controverse: prejudicieel verwijzen of niet?', $A A 2019$, afl. 6, p. 474 signaleren dat de meeste feitenrechters die geen hoogste rechter zijn, menen dat prejudiciële vragen een prerogatief van de hoogste rechter zijn, en dat sommige feitenrechters deze vragen, via de nationale prejudiciële procedure, overlaten aan de Hoge Raad. Zie ook J. Krommendijk, 'De lagere rechter aan banden. Is er nog ruimte voor de lagere rechter om te verwijzen naar het HvJ?', SEW 2018a, afl. 5, p. 185-187 en J. Krommendijk, 'Samenloop van de nationale en Unierechtelijke prejudiciële procedure: straight to the top of een hink-stap-sprong?', RMThemis 2018b, afl. 4, p. 149-158.

50. A-G Drijber, sub 4.34; Hof Amsterdam 8 oktober 2019, ECLI:NL:GHAMS:2019:3623, r.o.3.9.

51. J. Krommendijk, 'Van Middelburg tot Almelo. Het hoe en waarom van prejudiciële vragen aan het Hof van Justitie van de Europese Unie door Nederlandse lagere rechters', $R d W 2018 c$, afl. 3, p. 14-23; Langer \& Krommendijk 2019, p. 474, met een uitstapje naar de verwijzingspraktijk van niet-verwijzingsplichtige feitenrechters.

52. Krommendijk 2018c, p. 18-20 en 22; Langer \& Krommendijk 2019, p. 474 .

53. Krommendijk 2018c, p. 19-20. De verwijzingsplicht voor kantonrechters komt zelf als factor slechts marginaal naar voren; Krommendijk 2018c, p. 14.

54. Zie ter illustratie Rb. Den Haag 23 november 2016, ECLI:NL:RBDHA: 2016:14190, r.o. 4.24, waarin de kantonrechter geen prejudiciële vragen voorlegt aan het Hof van Justitie, ondanks verzoek daartoe van eiseres. Of twijfel heerst over de toepassing van Unierecht, is ook niet steeds makkelijk te bepalen, zie H.B. Krans, 'De veranderde rol van hoogste nationale rechters', TPR 2020, afl. 1/2, p. 9-11. Bovendien lijkt het Hof van Justitie de hoogste rechter in sommige omstandigheden onder het Cilfit-kader meer ruimte te geven om te besluiten in een specifieke zaak geen prejudiciële vraag te stellen. Daarvoor kan doorslaggevend zijn of de hoogste rechter al dan niet zelf twijfelt aan de uitleg van het Unierecht, waarbij de focus dus ligt op de subjectieve beleving van de hoogste rechter. Hierover Langer \& Krommendijk 2019, p. 471 en 475. vervolgens met lege handen, omdat daartegen gerichte klachten in zowel hoger beroep als cassatie onmogelijk zijn. Ook het blijven steken van Unierechtelijke uitlegvragen bij kantonrechters is niet bevorderlijk voor de eenvormige uitleg van het recht.

\section{Routes voor rechtsklachten}

\subsection{Mogelijke constructies voor uitbreiding}

Het Nederlandse procesrecht biedt aanknopingspunten om tegemoet te komen aan de wenselijkheid van ruimere mogelijkheden tot toetsing van kantonuitspraken. Hierna verken ik mogelijke constructies die corresponderen met de in paragraaf 2 geschetste beperkingen. Er kan worden gedacht aan een ruimere toepassing van de doorbrekingsleer bij art. 332 Rv. Deze optie is, zoals zal blijken, beperkt. Daardoor lijkt de tweede optie, afschaffing van het beperkte art. 80 lid 1 Wet RO, betere papieren te hebben. Een alternatief is een constructie waarin ruimere mogelijkheden tot toetsing van kantonuitspraken beperkt blijven tot gevallen waarin Unierecht wordt toegepast. Mijns inziens biedt het huidige systeem rechtvaardiging voor inpassing van deze mogelijkheid, ondanks de overwegingen van de Hoge Raad in de Ryanairzaak.

\subsection{Doorbreking van de appelgrens}

Het mogelijk maken van doorbreking van het appelverbod van art. $332 \mathrm{Rv}$ biedt niet direct soelaas om klachten over de toepassing van het recht door de kantonrechter aan de orde te kunnen stellen. Vaste rechtspraak is immers dat doorbreking van een rechtsmiddelenverbod slechts mogelijk is wanneer de rechter in vorige aanleg het artikel waarop de betreffende beslissing is gegrond ten onrechte heeft toegepast of niet toegepast, of zo fundamentele rechtsbeginselen heeft geschonden dat niet meer kan worden gesproken van een eerlijke en onpartijdige behandeling van de zaak. Klachten over onjuiste toepassing van rechtsregels geven op zichzelf genomen geen aanleiding om het appelverbod te mogen negeren. ${ }^{55}$

Een succesvol beroep op een doorbrekingsgrond zou echter op indirecte wijze wel ertoe kunnen leiden dat de juiste toepassing van het recht alsnog aan de orde wordt gesteld. Wanneer de doorbrekingsleer ook voor de appelgrens van art. $332 \mathrm{Rv}$ wordt aanvaard, kan het hof de aangevoerde doorbrekingsgrond beoordelen. Acht het hof het beroep op doorbreking gegrond, dan wordt de zaak ook voor het overige op het hof afgewenteld, hetgeen leidt tot een behandeling ten

55. Snijders \& Wendels 2009/321; Asser Procesrecht/Bakels, Hammerstein \& Wesseling-van Gent 4 2018/24; HR 24 april 1992, ECLI:NL:HR 1992:ZC0585, NJ 1992/672 (Woesthoff/Intershow), r.o. 3.4; HR 24 september 1993, ECLI:NL:HR:1993:ZC1076, NJ 1993/758 (BIS/Koster), r.o. 3.3; HR 27 mei 2011, ECLI:NL:HR:2011:BP9036, RvdW 2011/685, r.o. 3.3 
gronde door dat hof. ${ }^{56}$ Het hof kan vervolgens worden verleid om het recht alsnog goed toe te passen.

Bij deze mogelijkheid oordeelt direct een hogere feitenrechter over de kantonuitspraak. Daarin ligt een voordeel boven de door de Hoge Raad in Johannes/Baranco gekozen route van enerzijds handhaving van het appelverbod van art. 332 lid $1 \mathrm{Rv}$ en anderzijds uitbreiding van de mogelijkheid van cassatieberoep in geval van schending van zo fundamentele rechtsbeginselen dat geen sprake is van eerlijke en onpartijdige behandeling. De Hoge Raad zal immers bij gegrondverklaring van het cassatieberoep in de regel verwijzen naar hetzij de rechtbank, hetzij het hof om de zaak af te doen met inachtneming van voornoemde fundamentele rechtsbeginselen. ${ }^{57}$ Er wordt dan geprocedeerd tot de Hoge Raad, waarna een nieuwe behandeling door een feitenrechter plaatsvindt..$^{58}$ Dat oogt omslachtig en rijmt ook niet echt met de gedachte achter de appelgrens van art. 332 lid $1 \mathrm{Rv}$, namelijk dat belasting van partijen en de rechterlijke organisatie moet worden voorkomen. Bovendien is opmerkelijk dat juist waar het gaat om schending van fundamentele beginselen als hoor en wederhoor het terzijde schuiven van de doorbrekingsleer noodzaakt tot een extra stap in de procedure.

De indirecte mogelijkheid tot toetsing van toepassing van het recht vereist echter wel dat de Hoge Raad aanvaardt dat de appelgrens van art. $332 \mathrm{Rv}$ kan worden doorbroken. Vooralsnog blijkt het tegendeel uit zijn rechtspraak. ${ }^{59} \mathrm{De}$ overwegingen uit Johannes/Baranco blijven representatief:

'De Hoge Raad heeft eerder geoordeeld dat de uitsluiting van hoger beroep in dit soort zaken [waarin het betrekkelijk geringe financiële belang niet opweegt tegen de tijd en kosten die gemoeid zijn met behandeling in hoger beroep; $\mathrm{FB}]$ niet wordt doorbroken door, kort gezegd, de doorbrekingsgronden die hoger beroep wel mogelijk maken daar waar dat in bijzondere wetsbepalingen is uitgesloten (HR 19 december 1986, nr. 13218, NJ 1987, 1000; HR 12 april 1991, nr. 8740, NJ 1992, 215). In dat verband werd gewicht gehecht aan het openstaan van beroep in cassatie op de voet van (thans) art. 80 RO. ${ }^{60}$

Alleen met goede wil is hierin als volgt ruimte voor de doorbrekingsleer te lezen. Bij het buiten toepassing laten van de doorbrekingsleer benadrukt de Hoge Raad het openstaan van

56. Snijders \& Wendels 2009/324; HR 22 november 1996, ECLI:NL:HR: 1996:ZC2210, NJ 1997/204 (Yildiz/Jansen's Pluimveeslachterijen), r.o. 3.3; HR 21 september 2007, ECLI:NL:HR:2007:BA9614, NJ 2008/547 (Giskus/BMG), r.o. 3.9; HR 5 december 2014, ECLI:NL:HR: 2014:3536, NJ 2015/275 (Mataresse/Tiels Schoonmaakbedrijf), r.o. 3.4.3.

57. Art. 422a en 423 sub 1 Rv; N.T. Dempsey \& A.E.H. van der Voort Maarschalk, 'De procedure na vernietiging en verwijzing', in: B.T.M. van der Wiel (red.), Cassatie, Deventer: Wolters Kluwer 2019/376.

58. Zie HR 15 december 2017, ECLI:NL:HR:2017:3151, JBPr 2018/19, en daaronder Klaassen, sub 4.

59. Pavillon \& Bos 2020, p. 124-125 achten een doorbrekingsmogelijkheid, voor wat betreft art. 2 lid 2 UwEPGV, 'vooralsnog beperkt'. Zij lijken doorbreking echter niet uit te sluiten.

60. Johannes/Baranco, r.o. 3.6. cassatieberoep. ${ }^{61}$ Dat doet de Hoge Raad ook in het kader van andere appelverboden, zoals art. 388 lid 2 Rv (heropeningsbeslissingen) ${ }^{62}$ en art. $490 \mathrm{~d} \mathrm{Rv}$ (staat van verdeling van executieopbrengst). ${ }^{63} A$ contrario zou kunnen worden geredeneerd dat doorbreking wel mogelijk moet zijn wanneer cassatieberoep níet openstaat. Doorredenerend kan worden betoogd dat wellicht ruimte voor de doorbrekingsleer bestaat in gevallen waarin cassatie niet openstaat, omdat rechtsklachten tegen niet-appellabele kantonuitspraken op grond van art. 80 lid 1 Wet RO niet mogelijk zijn.

Dat de Hoge Raad ruimte voor deze gedachte laat, is niet aannemelijk. In Johannes/Baranco wordt het uitsluiten van de doorbrekingsleer gerechtvaardigd met de mogelijkheid om in cassatie te klagen over schending van fundamentele beginselen van procesrecht. De klachten waarop doorbrekingsgronden betrekking hebben, kunnen immers ook in cassatie aan de orde worden gesteld. ${ }^{64}$ Een redenering die een doorbrekingsmogelijkheid baseert op de onmogelijkheid om in cassatie materiële rechtsklachten aan te voeren, kan niet zomaar op die rechtspraak worden gebaseerd. Het afzien van doorbreking in het kader van art. 332 lid $1 \mathrm{Rv}$ wordt bovendien niet alleen gerechtvaardigd door de cassatiemogelijkheid. Het dient ook het doel van de appelgrens, en zorgt dat hoger beroep uitblijft waar het geringe financiële belang de tijd en kosten van hoger beroep niet rechtvaardigt, waardoor ook de toegang tot de rechter gewaarborgd blijft (par. 2.1). ${ }^{65}$

\subsection{Afschaffing van art. 80 lid 1 Wet RO}

Het alternatief is het openen van de mogelijkheid om in cassatie rechtsklachten aan te voeren tegen niet-appellabele kantonuitspraken. Dit komt neer op afschaffing van art. 80 lid 1 Wet $\mathrm{RO}$. Deze route is niet zo beperkt als de - indirect werkende doorbrekingsmogelijkheid en daarmee aantrekkelijker. Voor

61. Evenals Hof Arnhem-Leeuwarden 24 april 2018, ECLI:NL:GHARL: 2018:3835, r.o. 4.4. Zie Hof 's-Hertogenbosch 13 december 2012, ECLI:NL:GHSHE:2012:BZ1135, r.o. 4.9 inzake art. 2 lid 2 UwEPGV.

62. Betsalel/Stichting Joodse Omroep, r.o. 4.2.1. In dezelfde overweging blijkt overigens ook de aard van de beslissing - heropening staat slechts in zeer bijzondere gevallen open - relevant voor uitsluiting van doorbreking. Lewin, JBPr 2012/68, sub 7 onder het arrest, leidt uit de overwegingen nog niet met zekerheid af dat openstaan van cassatieberoep op zichzelf reeds een doorslaggevend argument is.

63. HR 27 januari 2017, ECLI:NL:HR:2017:112, NJ 2017/64 (ING/Visser \& Lucky Parrot), r.o. 4.2.

64. Johannes/Baranco, r.o. 3.7.2-3.8. Zie ook Betsalel/Stichting Joodse Omroep, r.o. 4.2.1. Hieraan doet niet af dat de mogelijke cassatiegronden op grond van art. 80 lid 1 Wet RO beperkter zijn dan in appel. Zie in het kader van de UwEPGV Hof Arnhem-Leeuwarden 11 april 2019, ECLI:NL:GHARL:2019:3239, 3245, 3247 en 3425.

65. Asser Procesrecht/Bakels, Hammerstein \& Wesseling-van Gent 4 2018/25; Van Geuns \& Jansen, in: GS Burgerlijke Rechtsvordering, art. 332, aant. 20; Hof 's-Hertogenbosch 12 juli 2016, ECLI:NL:GHSHE:2016:2836, r.o. 3.9; Hof's-Hertogenbosch 13 augustus 2019, ECLI:NL:GHSHE:2019:3023, r.o. 2.5. Hetzelfde geldt voor art. 2 lid 2 UwEPGV, zie Kamerstukken II 2007/08, 31596, nr. 3, p. 10 en Hof 's-Hertogenbosch 13 december 2012, ECLI:NL:GHSHE: 2012:BZ1135, r.o. 4.6-4.7 en 4.9, waaronder Zilinsky, TvC 2013, afl. 6, p. 298 en Pavillon \& Bos 2020, p. 124-125. A-G Drijber, ECLI:NL:PHR:2020:1085, sub 3.17 merkt op dat het principe, waarin het appelbeginsel wijkt voor het toegankelijkheidsbeginsel, teruggaat tot de negentiende eeuw. 
het openen van de mogelijkheid tot rechtsklachten in brede zin moet wel een beroep worden gedaan op de wetgever. De Hoge Raad heeft immers uitbreiding van art. 80 lid 1 Wet RO met rechtsklachten afgewezen. ${ }^{66}$ Mede gezien de overwegingen in paragraaf 3 , en ondanks vruchteloze betogen van andere auteurs, lijkt mij de heroverweging van een dergelijke wetswijziging passend.

Ik verwacht niet dat de mogelijkheid van rechtsklachten tegen thans niet-appellabele kantonuitspraken tot een grotere stroom aan zaken in cassatie zal leiden. De hoge kosten van cassatieprocedures zullen, bij de vaak relatief kleine belangen in een kantonzaak, beperkend werken. ${ }^{67}$ Dreigt toch onterecht gebruik te worden gemaakt van de nieuw beschikbaar te stellen mogelijkheid, dan kan de werklast van de Hoge Raad verder worden beperkt door niet-ontvankelijkverklaring met een beroep op art. 80a Wet $\mathrm{RO}^{68}$ of door verwerping met de beperkte motivering op grond van art. 81 lid 1 Wet RO. Ook op die wijze kan recht worden gedaan aan de ratio van art. 80 lid 1 Wet RO. Deze twee instrumenten had de Hoge Raad bij de inwerkingtreding van (de voorgangers van) art. 80 lid 1 Wet RO nog niet. Zij ontbreken in appel, waar de ontvankelijkheid met een beroep op een doorbrekingsgrond is gegeven. De beschikbaarheid van deze instrumenten in cassatie vormt een aanvullend argument voor de keuze voor afschaffing van art. 80 lid 1 Wet RO boven het faciliteren van doorbreking. Doorslaggevend lijkt mij echter dat deze route het meest effectief recht doet aan de aard van de mogelijk nieuw beschikbare rechtsklachten: de gezaghebbende beantwoording van rechtsvragen is in civielrechtelijk Nederland toch bij uitstek aan de Hoge Raad toevertrouwd. Dat geldt ook voor Unierechtelijke rechtsvragen. In dat licht doet deze route bovendien recht aan de veelgehoorde opvatting van feitenrechters dat het stellen van prejudiciële vragen aan het Hof van Justitie een prerogatief is van de Hoge Raad. ${ }^{69}$

\subsection{Uitbreiding beperkt tot zaken met een Unierechtelijke dimensie}

Een uitbreiding van de klachtmogelijkheden tegen thans nietappellabele kantonuitspraken zou beperkt kunnen blijven tot zaken in de Unierechtelijke sfeer. In het bijzonder gelet op de mogelijke nadelen van een kantonrechter die als hoogste nationale rechter Unierecht toepast (par. 3.2), is deze optie het overwegen waard.

Ook in dit verband moet de wetgever of de rechtspraak een horde nemen. De Hoge Raad heeft in de Ryanair-zaak in het kader van art. 80 lid 1 Wet RO de deur dichtgetrokken voor klachten over verkeerde toepassing van het Unierecht.

66. A-G Drijber, sub 4.26 en 4.45. Vgl. A-G Lückers, ECLI:NL:PHR: 2020:322, sub 2.16 inzake de beperkte cassatiemogelijkheid op grond van art. 4:218 lid $5 \mathrm{BW}$ jo. art. 187 lid $1 \mathrm{Fw}$, eveneens tegen niet-appellabele kantonbeslissingen. In HR 17 juli 2020, ECLI:NL:HR:2020:1306 werd het cassatieberoep in die zaak met toepassing van art. 81 lid 1 Wet RO verworpen.

67. Zie Janssens, JIN 2018/17, sub 8. Hetzelfde geldt voor (kosten in) hoger beroep.

68. Van der Voort Maarschalk 2019/97.

69. Zie voetnoot 49 en de daar vermelde literatuur.
Mijns inziens was een ander oordeel van de Hoge Raad niet ondenkbaar geweest. De aan het oordeel ten grondslag liggende overwegingen - het Unierecht vormt onderdeel van de Nederlandse rechtsorde en neemt voor de toepassing van art. 80 lid 1 Wet RO geen uitzonderingspositie in - laten enige ruimte voor toetsing door een hogere rechter van de toepassing van Unierecht in thans niet-appellabele kantonuitspraken.

Een status aparte van het Unierecht in procesrechtelijke zin is het Nederlandse privaatrecht op zichzelf namelijk niet vreemd. ${ }^{70}$ Een voorbeeld is het leerstuk van ambtshalve toetsing. De Hoge Raad oordeelt, in navolging van het Hof van Justitie, dat de rechter ambtshalve dient te toetsen aan bepaalde delen van het consumentenrecht met een Unierechtelijke achtergrond, zoals regelingen inzake oneerlijke bedingen en consumentenkrediet. ${ }^{71}$ Die plicht geldt niet per definitie voor nationaal consumentenrecht zonder Unierechtelijke tint, tenzij die nationale rechtsregels kwalificeren als recht van openbare orde. ${ }^{72}$ Aan die gevallen zou ook een argument kunnen worden ontleend voor een speciale positie van het Unierecht waar het ruimere mogelijkheden voor toetsing in hoger beroep of cassatie betreft. Nu veel niet-appellabele kantonuitspraken consumentenzaken zullen betreffen, krijgt dit argument extra kleur.

Ik sta in het bijzonder stil bij de aparte status van het Unierecht binnen het kader van de eerder besproken staatsaansprakelijkheid voor rechterlijke beslissingen. De Hoge Raad had al vóór Köbler een beoordelingskader voor staatsaansprakelijkheid wegens onrechtmatige rechtspraak ontwikkeld. In Hotel Jan Luyken (1971) laat de Hoge Raad slechts ruimte voor deze aansprakelijkheid 'indien bij de voorbereiding van een rechterlijke beslissing zo fundamentele rechtsbeginselen zijn veronachtzaamd dat van een eerlijke en onpartijdige behandeling van de zaak niet meer kan worden gesproken, en tegen die beslissing geen rechtsmiddel openstaat en heeft

70. Het binnen het Unierecht geldende doeltreffendheidsbeginsel vereist immers dat lidstaten hun interne rechtsorde zo inrichten dat de uitoefening van door het Unierecht toegekende rechten niet onmogelijk of uiterst moeilijk wordt gemaakt. In voorkomende gevallen wordt daarom van nationale regels of beperkingen afgeweken om de volle werking van Unierechtelijke regels te garanderen. Zie bijv. T.F.E. Tjong Tjin Tai, 'Effectiviteitsbeginsel en nationaal privaatrecht', WPNR 2011, afl. 6901, p. 790 en Asser/Hartkamp 3-I 2019/111, met verwijzing naar o.a. HvJ EG 9 december 2010, ECLI:EU:C:2010:751 (Spijker Infrabouw), r.o. 90-91.

71. Zie HR 13 september 2013, ECLI:NL:HR:2013:691, NJ 2014/274 (Heesakkers/Voets), HR 12 februari 2016, ECLI:NL:HR:2016:236, NJ 2017/282 (Lindorff/Nazier) en HR 8 november 2019, ECLI:NL:HR: 2019:1731, NJ 2020/305 (Stichting Intermaris), waarover A.S. Hartkamp, 'Ambtshalve toepassing in het Unierecht en het Nederlandse privaatrecht na het arrest van de Hoge Raad inzake Stichting Intermaris', in: R.H. de Bock, R.J.Q. Klomp \& E.L. Schaafsma-Beversluis (red.), Voor Daan Asser (Asser-bundel), Deventer: Wolters Kluwer 2020, p. 135-139. Zie ook A.G.F. Ancery \& H.B. Krans, 'Ambtshalve toepassing van consumentenrecht: grensbepaling en praktische kwesties', $A A$ 2016, afl. 11, p. 826-828.

72. Snijders, NJ 2020/305, sub 2; Ancery \& Krans 2016, p. 828. Overigens rechtvaardigt dit niet de conclusie dat ambtshalve toetsing alleen geldt voor bepalingen van openbare orde, zie Hartkamp 2020, p. 140-143. 
opengestaan (...)'. ${ }^{73}$ Inmiddels heeft ook de Hoge Raad aan de Köbler-criteria getoetst, en daarmee de Europese aansprakelijkheidsmaatstaf erkend. ${ }^{74}$ De eigen maatstaf van de Hoge Raad geldt na de komst van de Köbler-criteria alleen nog voor verkeerde toepassing van nationale regelgeving, zonder Unierechtelijke dimensie. ${ }^{75}$ Hoewel hierover in de literatuur discussie bestaat, ${ }^{76}$ lijkt die eigen maatstaf in die situaties - in ieder geval binnen de feitenrechtspraak - nog steeds leidend. ${ }^{77}$

Staatsaansprakelijkheid is onder deze zeer restrictieve maatstaf gereserveerd voor inbreuken op processuele regels. Dat ligt anders bij de - evenmin kinderachtige - Köbler-criteria, waar de vereiste 'kennelijke schending' van Unierecht ook een inbreuk op materieelrechtelijke regels kan betreffen. Even$\mathrm{min}$ is vereist dat de geschonden regels van fundamentele aard zijn. Welbeschouwd is de nationale rechter dus gehouden meer ruimte te laten voor staatsaansprakelijkheid wanneer de toepassing van een Unierechtelijke regel ter discussie staat. ${ }^{78}$

Deze status aparte van het Unierecht binnen het kader van staatsaansprakelijkheid wegens onrechtmatige rechtspraak biedt wellicht een opening voor eenzelfde status in het kader van beschikbare mogelijkheden tot beoordeling door een hogere nationale rechter. Die gedachte is allereerst ingegeven door de parallel tussen de doorbrekingsleer en staatsaansprakelijkheid in zuiver nationaalrechtelijke aangelegenheden. Doorbreking is immers mogelijk wanneer de rechter zo fundamentele rechtsbeginselen heeft geschonden dat van een eerlijke en onpartijdige behandeling van de zaak niet meer kan worden gesproken. ${ }^{79}$ Hier geldt dezelfde maatstaf als in Hotel Jan Luyken. ${ }^{80}$ Het gevolg is dat de Staat, bij een toepasselijk rechtsmiddelenverbod, nog niet aansprakelijk is bij fundamentele schendingen door de rechter. Doorbreking

73. HR 3 december 1971, ECLI:NL:HR:1971:AB6788, NJ 1972/137 (Hotel Jan Luyken).

74. KLM-piloten/Staat, r.o. 3.3.4 over een beslissing van de Hoge Raad zelf; Ortlep \& Widdershoven 2019, p. 45-46.

75. Vgl. Wissink \& Meijer 2004, p. 105.

76. HR 4 december 2009, ECLI:NL:HR:2009:BJ7834, NJ 2011/131 (Greenworld/NAI) en HR 30 september 2016, ECLI:NL:HR: 2016:2215, NJ 2017/141 (QNOW) bevatten een andere maatstaf - is opzettelijk of bewust roekeloos gehandeld, dan wel met kennelijke grove miskenning van hetgeen een behoorlijke taakvervulling meebrengt? -, maar omdat deze zaken arbitersaansprakelijkheid betroffen, is onduidelijk of deze maatstaf ook geldt voor overheidsrechters. Bevestigend o.a. I. Giesen, 'Greenworld en $Q N O W$ : staatsaansprakelijkheid wegens onrechtmatige rechtspraak', $O \mho A$ 2017/31, p. 74-76, Kortmann, JOR 2010/175, F. Fernhout, 'Onrechtmatige rechtspraak herzien', NJB 2011/2191, evenals Vranken, NJ 2011/131, sub 1 en - genuanceerder NJ 2017/141, sub 3. Ontkennend o.a. Barkhuysen \& Van Emmerik 2017, p. 102 en R. Meijer, 'Naar een ruimere aansprakelijkheid van arbiters?', $M v V$ 2010, afl. 2, p. 14. Ook Keus, NJ 2019/156, sub 3 ziet de Hotel Jan Luyken-maatstaf als leidend. KLM-piloten/Staat besliste de discussie niet, nu in cassatie niet werd geklaagd over de toepassing van de aansprakelijkheidsmaatstaven door het hof; Ortlep \& Widdershoven 2019, p. 46. Ik ga hieraan verder voorbij, zie nader Giesen 2017, p. 74-75.

77. Ortlep \& Widdershoven 2019, p. 45; Rb. Den Haag 8 april 2020, ECLI:NL:RBDHA:2020:3216, r.o. 4.6.

78. Barkhuysen \& Van Emmerik 2017, p. 105. Keus, NJ 2019/156, sub 2 en 4 en Wissink \& Meijer 2004, p. 109.

79. Enka/Dupont, r.o. 3.2; HBM/Wielenga, r.o. 3.3.

80. HR 3 december 1971, ECLI:NL:HR:1971:AB6788, NJ 1972/137 (Hotel Jan Luyken). schept dan immers extra aan te wenden rechtsmiddelen, terwijl voor aansprakelijkheid juist is vereist dat geen rechtsmiddel meer openstaat of heeft opengestaan. ${ }^{81}$

Dezelfde parallel bestaat tussen de uitbreiding van art. 80 lid 1 Wet RO in Johannes/Baranco en het Hotel Jan Luykencriterium. $^{82}$ De extra cassatiegrond maakt het immers mogelijk dat niet-appellabele kantonuitspraken toch kunnen worden getoetst op schending van fundamentele rechtsbeginselen tijdens de zaaksbehandeling. Hieruit blijkt het verband tussen de doorbreking van rechtsmiddelenverboden en de uitbreiding van art. 80 lid 1 Wet RO. ${ }^{83}$

Uit het voorgaande kan worden afgeleid dat het Unierecht, binnen de context van staatsaansprakelijkheid voor onrechtmatige rechtspraak, een status aparte kent. Tevens stel ik vast dat tussen die staatsaansprakelijkheid en uitbreiding van rechtsmiddelen een parallel bestaat. De status aparte kan langs die parallel evengoed worden doorgetrokken naar de mogelijkheid tot beoordeling van thans niet-appellabele kantonuitspraken door een hogere nationale rechter in zaken met een Unierechtelijke dimensie. Zo kan Köbler doorwerken in de ontsluiting van rechtsmiddelen naar nationaal procesrecht. ${ }^{84}$

In die doorwerking ligt tevens een aanvullende waarborg tegen onterecht en overmatig gebruik van de voorgestelde ruimere mogelijkheden. De weerspiegeling van de Köbler-maatstaf in de voorgestelde uitbreiding brengt logischerwijs mee dat de klachten tegen thans niet-appellabele kantonuitspraken zullen moeten worden ingericht conform de strenge Köblercriteria. ${ }^{85}$ Er moet dan worden geklaagd dat de schending van het Unierecht voldoende gekwalificeerd is, waarvoor slechts voldoende is de klacht dat de kantonrechter de toepasselijke Unierechtelijke regel kennelijk heeft geschonden. ${ }^{86}$

81. Heemskerk, NJ 1989/3; S.C.J.J. Kortmann, 'Onrechtmatige civiele rechtspraak', in: G.J.M. Corstens e.a. (red.), Met hoofd en hart (Leijtenbundel), Zwolle: W.E.J. Tjeenk Willink 1991, p. 276; S.C.J.J. Kortmann, 'Wie betaalt de rekening?', NJB 1993, p. 922; S.C.J.J. Kortmann, J.S. Kortmann \& L.P. Kortmann, 'Nogmaals de aansprakelijkheid van de Staat voor schade voortvloeiende uit rechterlijke uitspraken', in: P.T.T. Bovend'Eert e.a. (red.), Grensverleggend staatsrecht (Kortmann-bundel), Deventer: Kluwer 2001, p. 213-214; Asser/Hartkamp \& Sieburgh 6-IV 2015/389.

82. Vgl. A-G Drijber, sub 4.15.

83. Vgl. I. Giesen, Rechtsvorming in het privaatrecht, Deventer: Wolters Kluwer 2020/50, sub h; Van der Voort Maarschalk 2019/95; A-G Lückers, ECLI:NL:PHR:2020:322, sub 2.16; Snijders, NJ 2007/637, sub 2.

84. Ik heb geen uitgebreide aandacht besteed aan de mogelijkheid dat de Hotel Jan Luyken-maatstaf inmiddels door Greenworld/NAI is achterhaald (zie voetnoot 76). Nu de Greenworld-maatstaf evenmin is beperkt tot processuele schendingen, is gesuggereerd dat Greenworld toenadering zoekt tot het Köbler-criterium; vgl. Giesen 2017, p. 74 en Ortlep \& Widdershoven 2017, p. 114. Dat voedt het idee van doortrekken van de parallel naar gevallen binnen de Unierechtelijke sfeer en van doorwerking van Köbler in ontsluiting van rechtsmiddelen naar nationaal procesrecht.

85. Vgl. Barkhuysen \& Van Emmerik 2017, p. 105.

86. Waar mogelijk moet daarbij dan eveneens rekening worden gehouden met alle elementen die de voorgelegde situatie kenmerken, waaronder de gezichtspunten genoemd in par. 3.2. 


\section{Conclusie}

Art. 332 lid 1 Rv en art. 80 lid 1 Wet RO beperken rechtsmiddelen tegen uitspraken over vorderingen onder de appelgrens. Het gevolg is dat de kantonrechter soms als enige en hoogste rechter rechtsregels toepast en uitlegt. Hoger beroep is uitgesloten en in cassatie zijn slechts op beperkte gronden rechtsklachten mogelijk. Voor klachten over schending van Unierecht worden door de Hoge Raad thans geen uitzonderingen gemaakt. Bij deze beperkingen kunnen, wat betreft toepassing van zowel het recht in brede zin als van Unierecht, kanttekeningen worden geplaatst in het kader van rechtsbescherming, rechtsontwikkeling en rechtseenheid.

In mijn verkenning van meer mogelijkheden tot een gang naar de hogere rechter besprak ik enkele constructies. Een eerste optie is het aanvaarden van de doorbrekingsleer in het kader van de appelgrens van art. 332 lid 1 Rv. Via een succesvol beroep op een doorbrekingsgrond kan de toepassing van het recht door de kantonrechter dan aan een beoordeling door het hof worden onderworpen. Voordeel van deze mogelijkheid is dat zij bij klachten over schending van fundamentele rechtsbeginselen van procesrecht een extra stap naar de Hoge Raad voorkomt. Deze indirecte mogelijkheid is echter beperkt, omdat zij geen soelaas biedt waar gronden voor doorbreking afwezig zijn. Op klachten over onjuiste toepassing van rechtsregels kan op zichzelf geen doorbreking worden gebaseerd. Bovendien vereist deze mogelijkheid dat de Hoge Raad afwijkt van zijn lijn dat doorbreking van de appelgrens onmogelijk is. Uit zijn rechtspraak en de ratio die daarachter schuilt, blijkt niet dat de Hoge Raad daarvoor lijkt te voelen. Dit maakt het alternatief, ruimere mogelijkheden voor rechtsklachten in cassatie en afschaffing van art. 80 lid 1 Wet RO, aantrekkelijker. Deze route vereist echter aanpassing door de wetgever.

Ruimere mogelijkheden zouden ook beperkt kunnen blijven tot gevallen waarin toepassing van Unierecht aan de orde is. Hoewel de Hoge Raad een uitzonderingspositie van het Unierecht voor de toepassing van art. 80 lid 1 Wet RO recent heeft afgewezen, zie ik toch ruimte om van dit oordeel terug te komen, al dan niet via een wetswijziging. Een uitzonderingspositie van het Unierecht is het Nederlandse civiele recht, ook in procesrechtelijke zin, namelijk niet vreemd. Ik heb in het bijzonder gewezen op het verschil in maatstaf voor staatsaansprakelijkheid wegens onrechtmatige rechtspraak, al naar gelang sprake is van toepassing van nationaal recht of Unierecht. De parallel tussen de doorbrekingsleer en de uitbreiding van cassatiegronden in art. 80 lid 1 Wet RO (Johannes/Baranco) enerzijds, en de maatstaf voor staatsaansprakelijkheid wegens onrechtmatige rechtspraak in nationaalrechtelijke aangelegenheden (Hotel Jan Luyken) anderzijds, doet de vraag rijzen of de Hoge Raad de status aparte in het kader van de staatsaansprakelijkheid niet zou kunnen doortrekken tot ruimere klachtmogelijkheden tegen thans niet-appellabele kantonuitspraken. Overdadig gebruik van de voorgestelde uitbreidingen zou dan kunnen worden beperkt door doorwerking van de Köbler-criteria in de aan de klachten te stellen eisen. 